\title{
The Role of Glucose in the pH Regulation of Germ-tube Formation in Candida albicans
}

\author{
By JORDAN H. POLLACK AND TADAYO HASHIMOTO* \\ Department of Microbiology, Loyola University of Chicago, Stritch School of Medicine, \\ Maywood, IL 60153, USA
}

(Received 13 May 1986; revised 14 July 1986)

\begin{abstract}
It has been reported that Candida albicans can form germ-tubes only in the narrow pH range of $6-8$, and that by changing only the $\mathrm{pH}$ one can regulate germ-tube formation. We found that the $\mathrm{pH}$ minimum for germ-tube formation could be dramatically lowered by eliminating the glucose present in many induction solutions. Lee's medium lacking glucose, ethanol, $N$-acetyl-Dglucosamine, and proline induced germ-tubes at $\mathrm{pH}$ values as low as 3 under most conditions. The presence of as little as $1 \mathrm{mM}$-glucose in these induction solutions was sufficient to cause the cells to grow either as yeasts with multiple buds or as pseudohyphae when the $\mathrm{pH}$ was 3.7 . However, when $C$. albicans was grown in any of the above induction solutions (with the exception of ethanol), containing $200 \mathrm{mM}$-glucose buffered at $\mathrm{pH} 5 \cdot 8$, not only were germ-tubes formed, but their rate of formation and length were also increased. Preincubation of the cells in a solution buffered at $\mathrm{pH} 3.7$ and containing $200 \mathrm{~mm}$-glucose, before exposure to induction solutions lacking glucose at $\mathrm{pH} 3.7$ or at $\mathrm{pH} 5.8$, did not inhibit germ-tube formation. Likewise, addition of glucose after $45 \mathrm{~min}$ exposure to an induction solution was without effect. Theophylline and dibutyryl cAMP did not counteract the action of glucose. Other sugars which suppressed germ-tube formation at low $\mathrm{pH}$ were fructose, galactose, mannose, xylose, gluconic acid and the nonmetabolizable sugar 3-O-methylglucose. These results indicate that $\mathrm{pH}$ does not directly regulate dimorphism in C. albicans, and that glucose or its metabolites may play an important role.
\end{abstract}

\section{INTRODUCTION}

A number of factors are known to regulate the dimorphic transformation of Candida albicans from budding yeast cells to elongating hyphae, the most important being the growth medium and temperature. Specifically, when $C$. albicans yeast cells are transferred to a medium containing either certain amino acids (such as proline), $N$-acetyl-D-glucosamine (GlcNAc) or ethanol, and incubated at a temperature between 33 and $42{ }^{\circ} \mathrm{C}$, they are induced to grow by forming germ-tubes which elongate to form hyphae.

Although many groups have reported that germ-tube formation is restricted to the narrow $\mathrm{pH}$ range of 6-8 (Odds, 1979), only recently has $\mathrm{pH}$ been advanced as an equally important 'regulator' of $C$. albicans dimorphism. Buffo et al. (1984) presented evidence that as long as the $\mathrm{pH}$ of a medium allowing germ-tube formation is kept above $6, C$. albicans grows in the hyphal form. Should the $\mathrm{pH}$ drop below 6 , the cells revert to growing as a budding yeast. Using ethanol as an inducer of germ-tube formation (Pollack \& Hashimoto, 1985), we have shown that germtubes could form even when the $\mathrm{pH}$ was as low as 3.0 . This led us to look for an explanation for the differences between our findings and those of Soll and co-workers (Mitchell \& Soll, 1979; Buffo et al., 1984).

Abbreviations: LAA, Lee's amino acids; LM, Lee's medium; SDA, Sabouraud dextrose agar; SDB, Sabouraud dextrose broth; TAPS, tris(hydroxymethyl)methylaminopropanesulphonic acid. 
This paper attempts to show that it is glucose, present in many media including that of Lee $e t$ al. (1975) used by Soll and co-workers (Mitchell \& Soll, 1979; Buffo et al., 1984), which suppresses germ-tube formation when the $\mathrm{pH}$ is below 5.8 and that, therefore, $\mathrm{pH}$ can at most be considered an 'indirect' regulator of germ-tube formation.

\section{METHODS}

Organisms. C. albicans ATCC 58716 was routinely used for the experiments described in this paper. In some experiments C. albicans ATCC 10261 was used for comparative purposes. Cells were maintained on Sabouraud dextrose agar (SDA, Difco) at $20^{\circ} \mathrm{C}$.

Growth and preparation of organism. Yeast-phase cells were prepared by growing the cells on SDA for $24 \mathrm{~h}$ at $37^{\circ} \mathrm{C}$. In some experiments, cells were also prepared by growing them for $24 \mathrm{~h}$ at $37^{\circ} \mathrm{C}$ in Sabouraud dextrose broth (SDB) containing $0.1 \%$ yeast extract, or by growth in the medium of Lee et al. (1975) (referred to as 'Lee's medium', LM) for $48-72 \mathrm{~h}$ at $23^{\circ} \mathrm{C}$ as described by Buffo et al. (1984). The cells were collected and washed ten times with glass-distilled, deionized water by vacuum filtration on a Millipore filtration apparatus, the cells being resuspended in water by repeated suction and forcible ejection through a Pasteur pipette before each washing.

Induction of germ-tube formation. Washed C. albicans yeast-phase cells (final concn $3 \times 10^{6}$ cells ml$^{-1}$ ) were inoculated into a buffered solution (final volume, $0.5 \mathrm{ml}$ ), containing an inducer and the following salts: $\mathrm{FeSO}_{4}$ $\left(0 \cdot 1 \mathrm{mg} \mathrm{l}^{-1}\right) ; \mathrm{KCl}\left(400 \mathrm{mg} \mathrm{l}^{-1}\right) ; \mathrm{MgSO}_{4} \cdot \mathrm{H}_{2} \mathrm{O}\left(200 \mathrm{mg} \mathrm{l}^{-1}\right) ; \mathrm{NaH}_{2} \mathrm{PO}_{4} \cdot \mathrm{H}_{2} \mathrm{O}\left(125 \mathrm{mg} \mathrm{l}^{-1}\right) ; \mathrm{NaCl}\left(6400 \mathrm{mg} \mathrm{l}^{-1}\right)$; and $\mathrm{NaHCO}_{3}\left(750 \mathrm{mg} \mathrm{l}^{-1}\right)$. The buffers used were citrate phosphate (pH 2.5-6.5), HEPES (pH 7.0-8.0), MES (pH 5.5-6.5), succinate ( $\mathrm{pH} 4 \cdot 0-5 \cdot 0)$, Tris/maleate ( $\mathrm{pH} 5 \cdot 0-9 \cdot 0)$, transaconitate (2.5-6.0), and tris(hydroxymethyl)methylaminopropanesulphonic acid (TAPS, $\mathrm{pH} 7.5-9.5$ ). With the exception of citrate phosphate buffer, all buffers were adjusted to the desired $\mathrm{pH}$ with $\mathrm{NaOH}$. The concentration of the buffer salt was $0.05 \mathrm{M}$. The inducers used were GlcNAc, L-proline (4 mM), glucose plus $\mathrm{NH}_{4} \mathrm{Cl}$ (each $5 \mathrm{mM}$ ), ethanol $(17.1 \mathrm{mM}, 0.1 \% \mathrm{v} / \mathrm{v})$, and a solution containing the amino acids found in LM: L-alanine, $5.6 \mathrm{mM}$; L-leucine, $9.9 \mathrm{mM}$; L-lysine, $5.5 \mathrm{mM}$; Lmethionine, $0.7 \mathrm{mM}$; L-phenylalanine, $3.0 \mathrm{mM}$; L-proline, $4.3 \mathrm{mM}$; and L-threonine, $4.2 \mathrm{mM}$ (referred to as 'Lee's amino acids', LAA). The cells were incubated at $37^{\circ} \mathrm{C}$ in a water bath for $4 \mathrm{~h}$. The $\mathrm{pH}$ of each solution was determined at the beginning and end of each incubation with a digital Ionalyzer (Orion Research, model 701A) and a semi-micro, combination $\mathrm{pH} /$ reference electrode (no. 476050, Corning Glass Works, Medfield, Mass., USA). Preliminary experiments showed that $\mathrm{pH}$ did not vary by more than 0.3 units during the $4 \mathrm{~h}$ incubation period. The percentage of cells forming germ-tubes or multiple buds was measured by counting 100-200 cells (or cell clusters) in each sample with a phase contrast microscope (Nikon). A cell was considered multi-budded if two or more round or ellipsoidal (pseudohyphal) buds were attached to the mother cell: a cell was considered to have formed a germ-tube when a narrow tube, at least $2 \mu \mathrm{m}$ long and without a constriction at its base, extended from the mother cell. Each cluster of cells was considered as one unit so that 50 multi-budded clusters in a population containing an additional 50 single cells would mean that $50 \%$ of the population was multi-budded. Although, generally, germ-tubes were formed from single cells, in those instances when they were formed from budded cells they were counted as one 'germ-tube unit' regardless of whether both the mother and daughter or only one of them had a germ-tube. Germ-tube lengths were measured using an ocular micrometer.

Chemicals. Most of the sugars used in this study were obtained either from Nutritional Biochemicals or from Sigma. The exceptions were GlcNAc, glucosamine, sodium glucoheptonate and gulono-1,4,-lactone (Pfanstiel), glucose and glycerol (Mallickrodt) and lactose (J. T. Baker). HEPES, MES, TAPS, amino acids and dibutyryl cAMP were obtained from Sigma, theophylline from Calbiochem, and the salts used in the buffered salts solution from J. T. Baker. All chemicals were used without further purification.

\section{RESULTS}

\section{Influence of $\mathrm{pH}$ on induction of germ-tubes by different inducers}

The range of $\mathrm{pH}$ values which allowed germ-tube formation was tested using a number of different inducers. The results shown in Fig. 1 demonstrate that germ-tubes were induced in $C$. albicans by proline when the $\mathrm{pH}$ was between 3 and 9 . Almost identical results were obtained when proline was replaced by LAA or GIcNAc. If ethanol replaced proline, a similar result was obtained with the exception that the maximum proportion of cells forming germ-tubes was approximately $85 \%$ (see Pollack \& Hashimoto, 1985). Decreasing the concentration of inducer 100 -fold resulted in only a partial decrease in the percentage of cells forming germ-tubes at the $\mathrm{pH}$ extremes. The $\mathrm{pH}$ range at which germ-tube formation occurred was not altered by increasing the concentration of proline or GlcNAc 100-fold either. In other words, there 


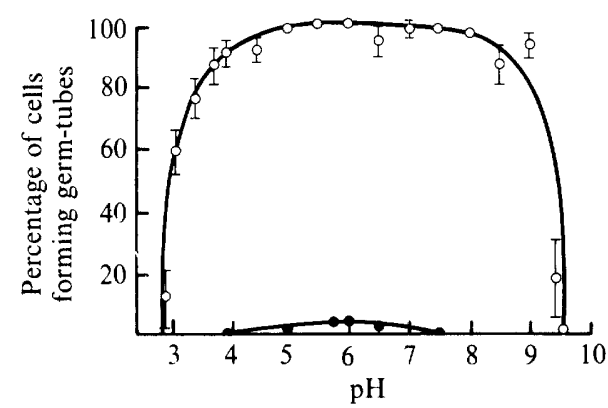

Fig. 1

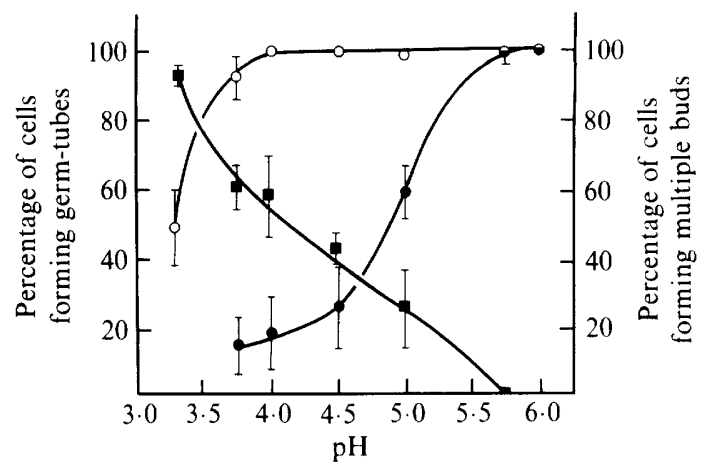

Fig. 2

Fig. 1. Infiuence of $\mathrm{pH}$ on germ-tube formation. C. albicans yeast cells were incubated for $4 \mathrm{~h}$ at $37^{\circ} \mathrm{C}$ in buffered salts solution $(O)$ or buffered salts solution containing $4 \mathrm{~mm}$-proline $(\mathrm{O})$. For buffers used to control the pH, see Methods. Values are the means of at least four independent experiments. Bars represent SD.

Fig. 2. Influence of glucose on germ-tube and multiple bud formation at different $\mathrm{pH}$ values. C. albicans yeast cells were incubated for $4 \mathrm{~h}$ at $37^{\circ} \mathrm{C}$ in buffered salts solution containing LAA in the presence (O) $\square$ ) or absence $(O)$ of $200 \mathrm{~mm}$-glucose. Similar curves were obtained if LAA was replaced by proline or GlcNAc. A curve similar to (O) was also obtained if the cells were induced by the combination of glucose and $\mathrm{NH}_{4} \mathrm{Cl}$, each at $5 \mathrm{mM}$. $\mathrm{O}$,, , Cells forming germ-tubes; $\mathbf{\square}$, cells forming multiple buds. The values are the means of four independent experiments. Bars represent SD.

\section{Table 1. Suppression by glucose at low $\mathrm{pH}$ of germ-tube formation induced by different compounds}

Cells were incubated with each individual inducer at pH 3.7 (except for ethanol, at pH 4.3) in the presence or absence of $200 \mathrm{~mm}$-glucose. Values represent the means of four to seven independent experiments $\pm \mathrm{SD}$

$\begin{array}{lcc}\text { Inducer } & \overbrace{\text { Glucose concn (mM) }}^{\text {Percentage of cells forming germ-tubes }} \\ \text { LAA } & 92.3 \pm 6.9 & 12.0 \pm 8.0 \\ \text { Proline } & 88.2 \pm 5.8 & 10.7 \pm 7.1 \\ \text { GlcNAc } & 93.5 \pm 4 \cdot 6 & 21 \cdot 2 \pm 7 \cdot 2 \\ \text { Ethanol } & 66.6 \pm 9.5 & 8.8 \pm 8.0\end{array}$

apparently is no sharply defined $\mathrm{pH}$ optimum for germ-tube formation. The addition of $200 \mathrm{mM}-$ glucose to LAA (Fig. 2) or the other inducers (Table 1) suppressed germ-tube formation when the $\mathrm{pH}$ was less than 5.8. The addition of glucose to ethanol-induced cells, however, suppressed germ-tube formation even above $\mathrm{pH} 5 \cdot 8$. Up to $90 \%$ of the cells which normally formed germtubes at $\mathrm{pH} 3.7$ were inhibited from doing so by the presence of glucose (Table 1). These results were not unique to strain ATCC 58716, but were also confirmed using strain ATCC 10261. In addition, since the cells used by Buffo et al. (1984) were grown initially in LM, yeast cells were prepared as they reported and by growth in SDB containing $0.1 \%$ yeast extract for $24 \mathrm{~h}$. These yeast cells were also tested for their ability to form germ-tubes at different $\mathrm{pH}$ values. The results (not shown) were essentially identical to those obtained using yeast cells grown on SDA.

\section{Concentration of glucose necessary for suppression of germ-tube formation}

The concentration of glucose in LM is fairly high ( $70 \mathrm{mM})$. We therefore tested the cells in the different induction media for the minimum concentration of glucose required to suppress germtube formation (Fig. 3). Even $1 \mathrm{~mm}$-glucose suppressed germ-tube formation at $\mathrm{pH} 3.7$. Increasing the concentration of glucose resulted in enhanced suppression of germ-tube 


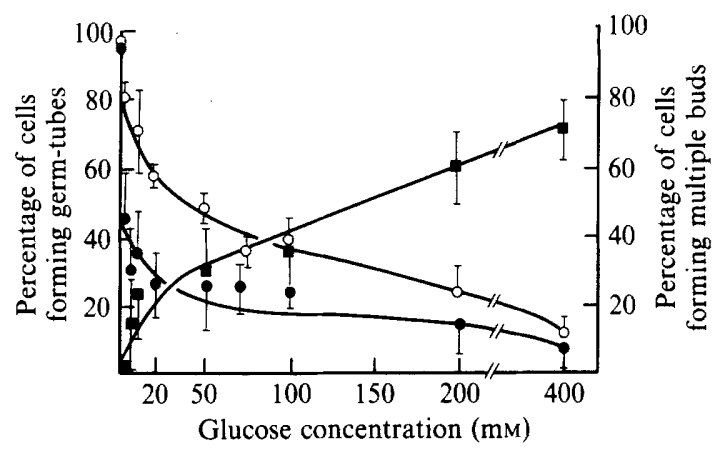

Fig. 3. Effect of increasing the glucose concentration on germ-tube and multiple bud formation in $C$. albicans yeast cells induced to form germ-tubes at $\mathrm{pH} 3 \cdot 7$. Cells were incubated for $4 \mathrm{~h}$ at $37^{\circ} \mathrm{C}$ in buffered salts solution containing LAA $(O, \square)$ or GlcNAc $(O)$. Curves essentially identical to and were obtained when LAA was replaced by proline. $\mathrm{O}, \mathrm{O}$, Cells forming germ tubes; $\square$, cells forming multiple buds. Values are the means of four independent experiments. Bars represent SD.

formation; however, even at the highest concentration of glucose tested (400 mM), germ-tube formation was never completely inhibited, approximately $10 \%$ of the cells still being capable of forming germ-tubes. Suppression was considerably greater (at all concentrations of glucose tested, except $400 \mathrm{mM}$ ) when the cells were induced by LAA or proline than when they were induced by GlcNAc. While germ-tube formation induced by LAA was suppressed approximately $67 \%$ and $84 \%$ by $5 \mathrm{mM}$ - and $200 \mathrm{~mm}$-glucose respectively at $\mathrm{pH} 3 \cdot 7$, it was only suppressed $18 \%$ and $76 \%$ respectively when induced by GIcNAc. Increasing the pH to 5.0 required greater amounts of glucose to obtain suppression than at $\mathrm{pH} 3.7$ (data not shown).

\section{Appearance of cells grown at low $\mathrm{pH}$ in the presence of glucose}

Yeast cells grown in non-germ-tube-inducing conditions (i.e. on SDA or in LM at room temperature) generally formed single buds, which separated from the mother cell before another bud was formed. Occasionally two buds could be seen attached to the mother cell. In contrast, cells grown in glucose at low $\mathrm{pH}$ tended to grow as pseudohyphae or as chains of yeast cells with multiple buds, which did not detach from the mother cell. As many as 12 cells could be seen attached together by the end of the $4 \mathrm{~h}$ period in which they were observed (Fig. 4). The number of cells forming multiple buds was also dependent on the $\mathrm{pH}$ and the concentration of glucose (Figs 2 and 3). The lower the $\mathrm{pH}$ and the higher the concentration of glucose, the more cells formed multiple buds. At $\mathrm{pH} 3.7$, approximately $60 \%$ of the cells induced by LAA formed multiple buds when exposed to 200 mM-glucose, while only $15 \%$ of those exposed to $5 \mathrm{mM}$ glucose did so (Fig. 3). At pH 5.0, only $25 \%$ of the cells exposed to $200 \mathrm{mM}$-glucose formed multiple buds (Fig. 2). Cells induced by GlcNAc formed fewer multiple buds than those induced by either LAA or proline. Only $39 \%$ of the cells induced by GlcNAc at pH 3.7 in the presence of $200 \mathrm{~mm}$-glucose formed multiple buds (data not shown).

\section{Time of exposure of cells to glucose necessary for suppression of germ-tube formation}

Yeast cells were exposed to $200 \mathrm{~mm}$-glucose at various times after induction by proline, to determine whether the cells always retain their susceptibility to suppression by glucose. The cells rapidly lost their ability to have germ-tube formation suppressed by glucose. When glucose was added $10 \mathrm{~min}$ after initiation of induction, $48 \%$ of the cells subsequently formed germ-tubes, while $73 \%$ of the cells did so when glucose was added 30 min after induction. By $45 \mathrm{~min}, 91 \%$ of the cells were committed to hyphal growth and further addition of glucose (up to $120 \mathrm{~min}$ ) did not cause the hyphal cells to revert to budding during the subsequent $4 \mathrm{~h}$ incubation period (data not shown). Furthermore, glucose suppressed germ-tube formation only as long as it remained in the medium. Yeast cells were preincubated for up to $4 \mathrm{~h}$ in the salts solution buffered at pH 3.7, containing LAA amd $200 \mathrm{~mm}$-glucose, before being washed by filtration. When the washed cells 

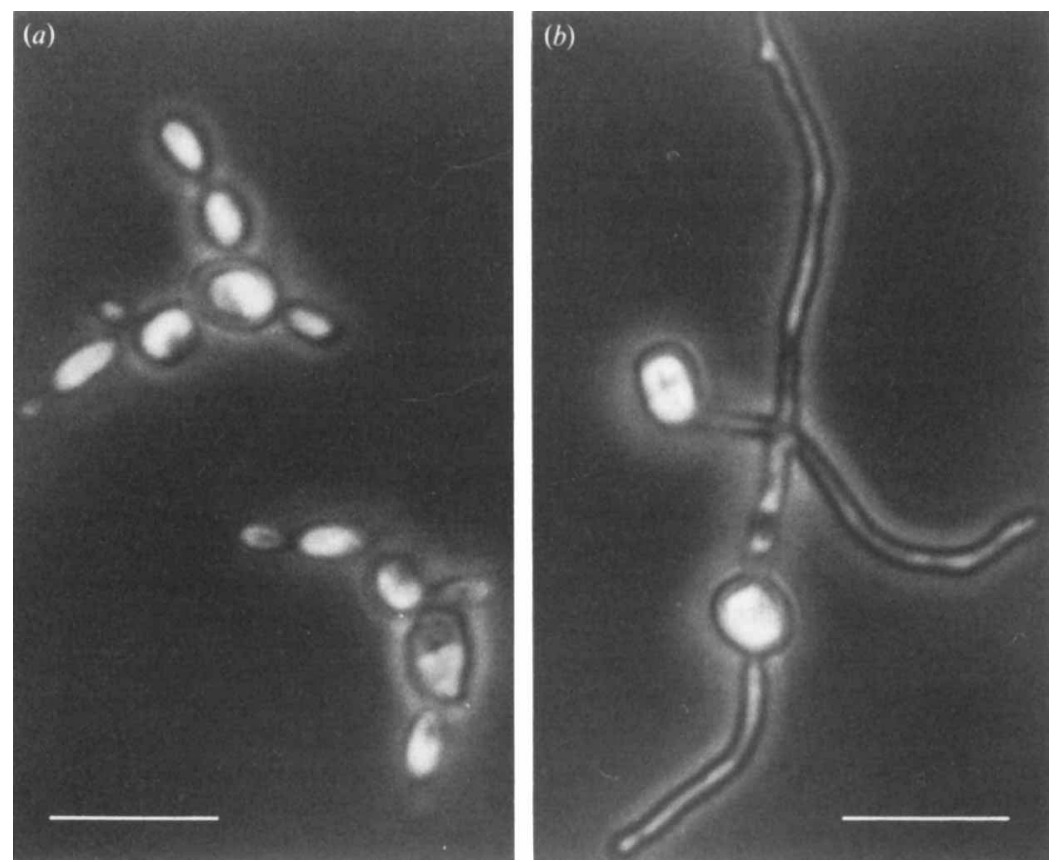

Fig. 4. Phase-contrast micrographs of $C$. albicans yeast cells ( $a$ ) grown for $4 \mathrm{~h}$ in the presence of LAA and $200 \mathrm{~mm}$-glucose at $\mathrm{pH} \mathrm{3.7}$, and $(b)$ induced to form germ-tubes by LAA in the absence of glucose at $\mathrm{pH} 3.7$ for $4 \mathrm{~h}$. Bars, $10 \mu \mathrm{m}$.

\section{Table 2. Relief of glucose suppression of germ-tube formation after removal of glucose}

Cells were incubated for the indicated time either in glucose $(200 \mathrm{~mm})$ plus salts solution or in LAA containing glucose $(200 \mathrm{mM})$ and salts, washed by filtration and returned to LAA at the indicated $\mathrm{pH}$. Values are the means of two or three independent experiments.

\begin{tabular}{|c|c|c|c|c|c|}
\hline \multirow{3}{*}{$\begin{array}{l}\text { Time } \\
\text { glucose } \\
\text { removed } \\
\text { (min) }\end{array}$} & & \multicolumn{4}{|c|}{$\begin{array}{l}\text { Percentage of cells forming germ-tubes when returned } \\
\text { to induction solution after exposure to: }\end{array}$} \\
\hline & & \multicolumn{2}{|c|}{$200 \mathrm{mM}$-glucose } & \multicolumn{2}{|c|}{$200 \mathrm{mM}$-glucose in LAA } \\
\hline & At $\mathrm{pH} \ldots$ & $3 \cdot 7$ & $5 \cdot 8$ & $3 \cdot 7$ & $5 \cdot 8$ \\
\hline 0 & & 92 & 100 & 92 & 100 \\
\hline 15 & & 87 & 93 & 96 & 98 \\
\hline 30 & & 86 & 98 & 90 & 98 \\
\hline 45 & & 82 & 95 & 91 & 98 \\
\hline 60 & & 83 & 96 & 79 & 95 \\
\hline 90 & & ND & 92 & 96 & 93 \\
\hline 120 & & 62 & 68 & 82 & 87 \\
\hline 150 & & ND & ND & 64 & 88 \\
\hline 180 & & 33 & 77 & 66 & 81 \\
\hline 240 & & 4 & 62 & 69 & 73 \\
\hline
\end{tabular}

ND, No data.

were reinoculated into the LAA induction solution, lacking glucose, at either $\mathrm{pH} 3.7$ or $5 \cdot 8$, no less than $70 \%$ of the cells still formed germ-tubes. When preincubated for $4 \mathrm{~h}$ in the buffered salts and glucose only, $62 \%$ of the cells formed germ-tubes when returned to the induction solution buffered at $5 \cdot 8$. Only if these cells were returned to the induction solution buffered at $3 \cdot 7$ was germ-tube formation inhibited. However, even here, if these cells were preincubated for only $2 \mathrm{~h}, 62 \%$ of the cells formed germ-tubes (Table 2 ). These results may have been affected by budding of the cells in the preincubation solution, and possible cell cycle changes. 


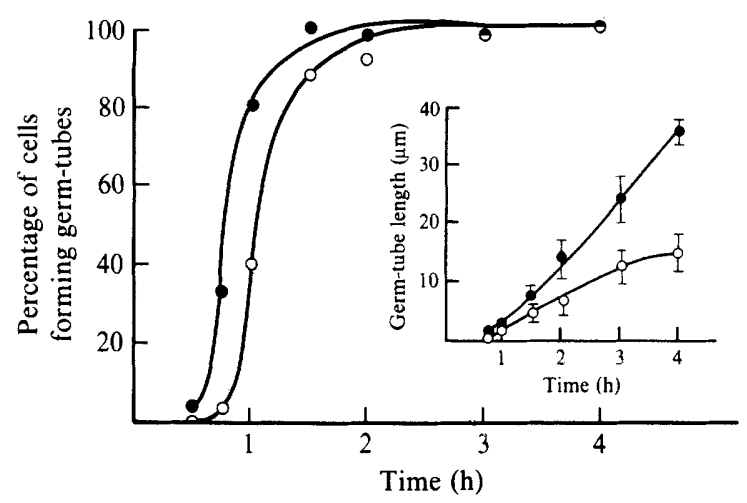

Fig. 5. Kinetics of germ-tube formation in the presence and absence of glucose at pH 5.8. C. albicans yeast cells were induced to form germ-tubes at $\mathrm{pH} 5.8$ and $37^{\circ} \mathrm{C}$ by $4 \mathrm{~mm}$-proline in buffered salts solution in the presence $(O)$ or absence $(O)$ of $200 \mathrm{~mm}$-glucose. The average length of 50 germ-tubes formed at each interval is indicated in the inset. Values are the result of a representative experiment. Bars represent SD.

\section{Table 3. Suppression of germ-tube formation by other sugars}

Cells were induced with LAA, to which $200 \mathrm{mM}$ (except where indicated otherwise) of the compounds listed was added. The values are the means \pm SD of three or more independent experiments. The following were inhibitory either to growth or to germ-tube formation at both $\mathrm{pH}$ values: 2-deoxyglucose (1 mM), 2-deoxygalactose (10 mM), galactono-1,4-lactone, glucone-1,5-lactione, glucuronic acid and Lsorbose. The following had no effect on germ-tube formation at either $\mathrm{pH}$ value: glyceric acid, glycerol, erythritol, ribose, L-arabinose, D-arabinose, dulcitol, sorbitol, $\alpha$-methylglucose, gulono-1,4-lactone, mannono-1,4-lactone, glucose 1-phosphate, glucosaminic acid, 6-phosphogluconic acid, glucoheptonic acid, mannoheptulose, cellobiose, lactose, melibiose, sucrose, trehalose, melezitose and raffinose.

\begin{tabular}{lrr} 
Compound & At pH $\ldots$ & \multicolumn{1}{c}{$\begin{array}{c}\text { Percentage of cells } \\
\text { forming germ-tubes }\end{array}$} \\
actose & $27.3 \pm 12.9$ & $90.0 \pm 9.6$ \\
gnose & $10.0 \pm 1.7$ & $97.0 \pm 2.6$ \\
ctose & $22.0 \pm 5.6$ & $97.7 \pm 2.5$ \\
ose & $9.3 \pm 5.5$ & $79.3 \pm 6.8$ \\
conic acid & $7.3 \pm 4.5$ & $91.3 \pm 7.5$ \\
cosamine & $17.3 \pm 3.2$ & $7.8 \pm 4.3$ \\
Methylglucose & $5.6 \pm 3.4$ & $94.6 \pm 3.4$ \\
cose (80 mM) & $82.7 \pm 3.2$ & $93.0 \pm 2.0$ \\
hamnose & $94.6 \pm 4.7$ & $93.3 \pm 4.9$
\end{tabular}

Suppression of germ-tube formation by other sugars and related compounds

Galactose, mannose, fructose, xylose and gluconic acid also suppressed germ-tube formation at $\mathrm{pH}$ values below $5 \cdot 8$, but not above that value. Glucosamine inhibited germ-tube formation even when the $\mathrm{pH}$ value was greater than 5.8 if its concentration was above $20 \mathrm{~mm}$. However, at a concentration of $4 \mathrm{mM}$, glucosamine induced about $60 \%$ of the cells to form germ-tubes (data not shown). The non-metabolizable glucose analogue 3- $O$-methylglucose also suppressed germtube formation at $\mathrm{pH} 3 \cdot 7$. However, L-fucose, and L-rhamnose, which are also thought not to be metabolized by the cell, did not affect germ-tube formation (Table 3 ).

\section{Suppression by glucose of other growth parameters at pH 5.8}

Although glucose was shown not to affect germ-tube formation at $\mathrm{pH}$ values above $5 \cdot 8$, we wished to determine whether it had any suppressive effects on growth at the higher $\mathrm{pH}$ values. We examined the kinetics of germ-tube formation and germ-tube length in the presence and absence of glucose at pH 5.8 (Fig. 5). In both instances, glucose was stimulatory. In the presence 
of glucose, germ-tube formation could be observed approximately 15 min earlier and the length of germ-tube after $4 \mathrm{~h}$ was more than twice that of those formed in the absence of glucose $(35 \mu \mathrm{m}$ versus $14 \mu \mathrm{m})$.

\section{Effect of cAMP on suppression of germ-tube formation}

Since the effect of glucose appeared to be similar to that of catabolite repression in bacteria, we examined whether cAMP or theophylline had any effect on the suppression of germ-tube formation. Neither dibutyryl cAMP (4 mM), nor theophylline ( $5 \mathrm{mM})$, had any effect on germtube formation in the presence or absence of $200 \mathrm{mM}$-glucose (data not shown).

\section{DISCUSSION}

Both glucose and $\mathrm{pH}$ have been reported individually to influence the ability of $C$. albicans to form germ-tubes. To our knowledge, this is the first report which demonstrates a relationship between the effects of $\mathrm{pH}$ and glucose.

The effect of glucose on germ-tube formation in $C$. albicans has been a matter of dispute. Nickerson \& Mankowski (1953) first reported that glucose inhibited filamentation in $C$. albicans. Widra (1964) reported that cells grown on neopeptone agar containing potassium phosphate, but lacking glucose, formed mycelia, while those grown on the same agar containing $0.25 \%$ glucose grew in the yeast-phase. Dabrowa et al. (1976) found that glucose concentrations as low as $1 \mathrm{mM}$ suppressed germ-tube formation induced by proline at $\mathrm{pH} 7 \cdot 0$. Odds et al. (1978) reported that while peptones containing $0.2 \%$ glucose were equally effective in inducing germtubes, Mycophil broth, which contained a preformulated glucose concentration of $4 \%$, did not support germ-tube production above the control levels. Hrmová \& Drobnica (1981) observed that exposure to an initial glucose concentration greater than $10 \mathrm{~mm}$ resulted in suppression of germ-tube formation at $28^{\circ} \mathrm{C}, \mathrm{pH} 6 \cdot 5$, in cells induced by glucose plus $\left(\mathrm{NH}_{4}\right)_{2} \mathrm{SO}_{4}$. Nolting et al. (1982) also reported that glucose concentrations above $1 \mathrm{mg} \mathrm{ml}^{-1}$ suppressed germ-tube formation. Conversely, Nishioka \& Silva-Hutner (1974) found that $2 \%$ glucose did not suppress germ-tubes induced by glutamate, while Evans et al. (1975b) found that even $20 \%$ glucose had no effect on germ-tube formation induced by peptone at $\mathrm{pH} 7 \cdot 4$. Barlow et al. (1974) also reported that glucose $(10 \mathrm{mM})$ was required to maintain filamentation induced by serum, and Land et al. (1975) reported that $1 \mathrm{M}$-glucose was necessary to obtain moderate filamentation in the presence of $\mathrm{NH}_{4} \mathrm{Cl}$.

Similarly, differences have been reported as to the effect of $\mathrm{pH}$ on germ-tube formation. Most workers have reported a $\mathrm{pH}$ optimum for germ-tube formation which varies from approximately 6.6 to 7.4 (Evans et al., 1975 b; Simonetti et al., 1974; Buffo et al., 1984). There are only a few reports of germ-tube formation occurring below pH 6.0 (McClary, 1952; Shepherd \& Sullivan, 1976), and only one previous report of germ-tube formation occurring as low as pH 3.0 (Pollack \& Hashimoto, 1985). This is despite the fact that $C$. albicans is known to grow at very low $\mathrm{pH}$ values (Odds \& Abbott, 1980) and that the $\mathrm{pH}$ of the human vagina, a common site for Candida infections, is between 4 and 5 (Ryley, 1986).

The results presented in this paper suggest that the dearth of reports showing the ability of $C$. albicans to form germ-tubes at low $\mathrm{pH}$ values may, in part, be due to the presence of glucose in the induction solutions used by many groups. Unlike the solutions used here, many induction solutions are poorly buffered, so that even if the initial $\mathrm{pH}$ would have allowed germ-tube formation to occur in the presence of glucose, a quick drop in $\mathrm{pH}$ could suppress germ-tube formation. In fact, just increasing the $\mathrm{pH}$ of a non-inducing solution, such as SDB, to 7.5 was sufficient to allow germ-tube formation to occur (Evans et al., 1974). We also found that buffering SDB at pH 5.8 resulted in germ-tube formation (data not shown). This is not to say that other factors do not affect the ability of $C$. albicans to form germ-tubes at non-optimal $\mathrm{pH}$ values. Shepherd et al. (1980) showed that the buffer used may also affect the ability of the cells to form germ-tubes. We have found that the concentration of $\mathrm{NaCl}$ created by adjusting the $\mathrm{pH}$ of some buffers such as Tris/maleate with $\mathrm{NaOH}$ may also inhibit germ-tube formation under certain conditions. Thus, we found that few germ-tubes were formed above $\mathrm{pH} 7.5$ when cells were 
induced by a low concentration of proline or GlcNAc $(0.08 \mathrm{mM})$ if Tris/maleate was used as the buffer, but almost all cells produced germ-tubes if HEPES or TAPS were used (data not shown). Others have also suggested that inorganic phosphate affects the ability of $C$. albicans to form germ-tubes (Widra, 1964; Dabrowa et al., 1975; Odds et al., 1978).

The results presented here do not agree with the recently proposed $\mathrm{pH}$ regulation of germ-tube formation in C. albicans (Mitchell \& Soll, 1979; Buffo et al., 1984). The proposal of Soll and coworkers is based on the assumption that germ-tube or bud formation can be controlled solely by regulating the $\mathrm{pH}$ of the inducing solution, similar to the more common temperature or nutritional regulation of germ-tube formation. Their proposal is tempered by the statement that there are variant strains which are capable of forming germ-tubes at $\mathrm{pH}$ values below $4 \cdot 0$, and that their transition points are 'rigidly defined only for the environmental conditions and growth history of the cells' induced under their experimental regimen (Buffo et al., 1984). However, we were able to reproduce their results with different strains and under different growth conditions. Since, by only removing glucose from several induction media, we were able to obtain germtubes at $\mathrm{pH}$ values as low as $3 \cdot 0$, we believe that $\mathrm{pH}$ cannot be considered a sole determinant of germ-tube formation. At most, $\mathrm{pH}$ can be considered an 'indirect' regulator or coregulator of dimorphism in $C$. albicans.

When grown in the presence of glucose at low pH values, the budding cells, also, apparently did not separate, which resulted in the formation of large clusters of multiple-budded cells or pseudohyphae. Similar modes of growth have been reported previously in response to glucose at lower temperatures (Soll \& Bedell, 1978; Dujardin et al., 1980). It might be useful to use this phenomenon to distinguish between growing and non-growing cells at low $\mathrm{pH}$ or low temperatures.

The results presented here differ from those of others also with respect to commitment to germ-tube formation. We found that by $45 \mathrm{~min}$ germ-tube formation could no longer be suppressed by the addition of glucose, while in most situations tested, removal of glucose resulted in cessation of suppression. It would seem, therefore, that $C$. albicans is committed to hyphal formation very early, but is never committed to the budding form of growth. The time for commitment to germ-tube formation compares favourably with those reported by Evans et al. (1975a) and Chaffin \& Wheeler (1981). However, those studies and that of Mitchell \& Soll (1979) also found that at some point the cells were committed to budding. Besides using different criteria (temperature or $\mathrm{pH}$ shift) to determine commitment, it is possible that the previously mentioned experimenters did not allow sufficient time after switching the growth conditions to properly assess the pluripotency of the cells to form germ-tubes. The cells in the present study were incubated for $4 \mathrm{~h}$ post-transfer, while cells used by both Mitchell \& Soll (1979) and Chaffin \& Wheeler (1981) were incubated for a total of only $4 \mathrm{~h}$, including the time before the switch in growth conditions. Furthermore, the previous authors claimed that $C$. albicans yeast cells must be in stationary phase in order for germ-tube formation to proceed. This claim has been questioned by others (Mattia \& Cassone, 1979; Ahrens et al., 1983; Soll \& Herman, 1983). However, it is possible that the extensive washing that the cells received before their transfer to the new growth conditions was equivalent to the starvation period which Soll \& Herman (1983) found sufficient to activate the cells, although it was for a much shorter period (4-5 min).

Suppression by glucose of differentiation in other organisms has been reported. BartnickiGarcia (1968) reported that glucose inhibited initiation of filamentation, but not hyphal elongation, in Mucor rouxii. Redshaw et al. (1976) observed that some Streptomyces species were inhibited from forming aerial mycelia in the presence of glucose only when the $\mathrm{pH}$ was between 5 and $5 \cdot 5$, but not when the $\mathrm{pH}$ value was higher. These reports, and those on glucose repression in $C$. albicans, suggest that the action of glucose is mediated by catabolite repression or inactivation. The data presented here are inconclusive in regard to whether a catabolic product of glucose is mediating the effect since, in addition to the other sugars, a supposedly nonmetabolizable analogue of glucose also suppressed germ-tube formation. However, cAMP did not seem to mediate the effect. This was unexpected, since cAMP has been reported to affect dimorphism in C. albicans (Niimi et al., 1980; Chattaway et al., 1981). On the other hand, it is not clear what role cAMP plays in catabolite repression in yeasts (Eraso \& Gancedo, 1984, 
1985). The mode of action of glucose remains to be determined. Some interesting possibilities suggested by others are: increasing the rate of proteolytic degradation of the nutrient inducer transport system (Horák \& Ř́hová, 1982); the suppression of production of some key enzyme such as chitinase (Monreal \& Reese, 1969); or the repression of the catabolic pathway for the inducer (Singh \& Datta, 1978).

This research was supported in part by a grant from the Otsuka Pharmaceutical Factory, Inc. J.H.P. was supported by a fellowship from Loyola University of Chicago.

\section{REFERENCES}

Ahrens, J. C., Price, M. R., Daneo-Moore, L. \& BUCKLEY, H. R. (1983). Effects of culture density on the kinetics of germ tube formation in Candida albicans. Journal of General Microbiology 129, 30013006.

Barlow, A. J. E., Aldersley, T. \& Chattaway, F. W. (1974). Factors present in serum and seminal plasma which promote germ-tube formation and mycelial growth of Candida albicans. Journal of General Microbiology 82, 261-272.

BarTNICKI-GaRCIA, S. (1968). Control of dimorphism in Mucor by hexoses: inhibition of hyphal morphogenesis. Journal of Bacteriology 96, 1586-1594.

Buffo, J., Herman, M. A. \& Soll, D. R. (1984). A characterization of pH-regulated dimorphism in Candida albicans. Mycopathologia 85, 21-30.

Chaffin, W. L. \& Wheeler, D. E. (1981). Morphological commitment in Candida albicans. Canadian Journal of Microbiology 27, 131-137.

Chattaway, F. W., Wheeler, P. R. \& O'Reilly, J. (1981). Involvement of adenosine $3^{\prime}: 5^{\prime}$-cyclic monophosphate in the germination of blastospores of Candida albicans. Journal of General Microbiology 123, 233-240.

Dabrowa, N., Taxer, S. S. S. \& Howard, D. H. (1976). Germination of Candida albicans induced by proline. Infection and Immunity 13, 830-835.

Dujardin, L., Waldbaum, S. \& Biguet, J. (1980). Influence de la concentration du glucose et de l'azote sur la morphologie de Candida albicans et la formation de ses chlamydospores dans un milieu de culture synthétique. Mycopathologia 71, 113-118.

Eraso, P. \& Gancedo, J. M. (1984). Catabolite repression in yeasts is not associated with low levels of cAMP. European Journal of Biochemistry 141, 195198.

ERaSo, P. \& Gancedo, J. M. (1985). Use of glucose analogues to study the mechanism of glucosemediated cAMP increase in yeast. FEBS Letters 191 , $51-54$.

Evans, E. G. V., Odds, F. C., Richardson, M. D. \& Holland, K. T. (1974). The effect of growth medium on filament production in Candida albicans. Sabouraudia 12, 112-119.

Evans, E. G. V., Odds, F. C. \& Holland, K. T. $(1975 a)$. Resistance of the Candida albicans filamentous cycle to environmental change. Sabouraudia 13, 231-238.

Evans, E. G. V., Odds, F. C., Richardson, M. D. \& Holland, K. T. (1975b). Optimum conditions for initiation of filamentation in Candida albicans. Canadian Journal of Microbiology 21, 338-342.
HoRÁx, J. \& Ř́́HOVÁ, L. (1982). L-Proline transport in Saccharomyces cerevisae. Biochimica et biophysica acta 691, 144-150.

Hrmová, M. \& DrobnicA, L. (1981). Induction of mycelial type of development in Candida albicans by low glucose concentration. Mycopathologia 76, 8396.

LAND, G. A., MCDONALD, W. C., StJernholm, R. L. \& Friedman, L. (1975). Factors affecting filamentation in Candida albicans: relationship of the uptake and distribution of proline to morphogenesis. Infection and Immunity 11, 1014-1023.

LeE, K. L., Buckley, H. R. \& Campbell, C. C. (1975). An amino acid liquid synthetic medium for the development of mycelial and yeast forms of Candida albicans. Sabouraudia 13, 148-153.

MATTIA, E. \& CASSONE, A. (1979). Inducibility of germtube formation in Candida albicans at different phases of yeast growth. Journal of General Microbiology 113, 439-442.

MCCLARY, D. O. (1952). Factors affecting the morphology of Candida albicans. Annals of the Missouri Botanical Garden 39, 137-164.

Mitchell, L. H. \& Soll, D. R. (1979). Commitment to germ tube or bud formation during release from stationary phase in Candida albicans. Experimental Cell Research 120, 167-179.

Monreal, J. \& ReEse, E. T. (1969). The chitinase of Serratia marcescens. Canadian Journal of Microbiology 15, 689-696.

Nickerson, W. J. \& MANkowski, Z. (1953). Role of nutrition in the maintenance of the yeast shape in Candida. American Journal of Botany 40, 584-592.

Nimi, M., Nilmi, K., Tokunaga, J. \& Nakayama, H. (1980). Changes in cyclic nucleotide levels and dimorphic transition in Candida albicans. Journal of Bacteriology 142, 1010-1014.

Nishioka, Y. \& Silva-Hutner, M. (1974). Dimorphism, sensitivity to nystatin and acriflavin uptake in a strain of Candida albicans grown with glutamate as sole nitrogen and carbon source. Sabouraudia 12, 295-301.

Nolting, S., Hagemeier, H. H. \& Fegeler, K. (1982). Effect of insulin on germ tube and mycelial formation of Candida albicans. Mykosen 25, 3641.

ODDs, F. C. (1979). Candida and Candidosis. Baltimore: University Park Press.

OdDS, F. C. \& Aввотт, A. B. (1980). A simple system for the presumptive identification of Candida albicans and differentiation of strains within the species. Sabouraudia 18, 301-317. 
Odds, F. C., Hall, C. A. \& Abbott, A. B. (1978). Peptones and mycological reproducibility. Sabouraudia 16, 237-246.

Pollack, J. H. \& Hashimoto, T. (1985). Ethanolinduced germ tube formation in Candida albicans. Journal of General Microbiology 131, 3303-3310.

Redshaw, P. A., McCanN, P. A., Sankaran, L. \& PoGell, B. M. (1976). Control of differentiation in streptomycetes: involvement of extra chromosomal deoxyribonucleic acid and glucose repression in aerial mycelia development. Journal of Bacteriology 125, 698-705.

RYLEY, J. F. (1986). Pathogenicity of Candida albicans with particular reference to the vagina. Journal of Medical and Veterinary Mycology 24, 5-22.

Shepherd, M. G. \& Sullivan, P. A. (1976). The production and growth characteristics of yeast and mycelial forms of Candida albicans in continuous culture. Journal of General Microbiology 93, 361-370.

ShePherd, M. G., Chiew, Y. Y., RaM, S. P. \& Sullivan, P. A. (1980). Germ tube induction in Candida albicans. Canadian Journal of Microbiology 26, 21-26.
Simonetti, N., Strippoli, V. \& Cassone, A. (1974). Yeast-mycelial conversion induced by $N$-acetyl-Dglucosamine in Candida albicans. Nature, London 250, 344-346.

SINGH, B. R. \& DATTA, A. (1978). Glucose repression of the inducible catabolic pathway for $N$-glucosamine in yeast. Biochemical and Biophysical Research Communications 84, 58-64.

Soll, D. R. \& Bedell, G. W. (1978). Bud formation and the inducibility of pseudo-mycelium outgrowth during release from stationary phase in Candida albicans. Journal of General Microbiology 108, 173180.

Soll, D. R. \& Herman, M. A. (1983). Growth and inducibility of mycelium formation in Candida albicans: a single-cell analysis using a perfusion chamber. Journal of General Microbiology 129, 28092824.

WIDRA, A. (1964). Phosphate directed $\mathrm{Y}-\mathrm{M}$ variation in Candida albicans. Mycopathologia 23, 197-202. 